\title{
Exploratory Research on Relationship between Entrepreneurial Orientation Dimensions and Business Performance and Growth of Fast and Slow Growing Small and Medium Enterprises in Bosnia and Herzegovina
}

\author{
Ramo Palalic ${ }^{1} \&$ Senad Busatlic ${ }^{1}$ \\ ${ }^{1}$ Faculty of Business Administration, International University of Sarajevo, Sarajevo, Bosnia and Herzegovina \\ Correspondence: Ramo Palalic, Faculty of Business Administration, International University of Sarajevo, \\ Sarajevo, Hrasnicka cesta 15, 71210 Sarajevo, Bosnia and Herzegovina. Tel: 387-3395-7401. E-mail: \\ rpalalic@ius.edu.ba
}

Received: November 21, 2014

Accepted: December 12, 2014

Online Published: January 20, 2015

doi:10.5539/ijbm.v10n2p15

URL: http://dx.doi.org/10.5539/ijbm.v10n2p15

\begin{abstract}
This paper analyses environment in fast (gazelles) and slow growing companies (mices) using Entrepreneurial orientation (EO) dimensions and business performance in terms of sales and employee growth. The research is done using information on 178 small and medium enterprises (SMEs) in Bosnia and Herzegovina. We find that EO dimensions are more present in gazelles than in mices. We show a small to moderate significant correlation between EO dimensions and business performance of gazelles and mices. Also, any change in sales growth and employee growth might be associated with variability in innovation, risk taking and firm's age.
\end{abstract}

Keywords: SMEs, gazelles, mices, growth, business performance, entrepreneurial orientation, sales growth, employee growth

\section{Introduction}

Small and medium enterprises (SMEs) in general, they have more positive effect if they employ entrepreneurial orientation (Lee \& Lim, 2009). SMEs drive a lot attention in the business world today and they can have different growth and development which reflects their capability of creating more or less jobs in the market. This paper addresses application of the EO dimensions in fast and slow growing companies - "gazelles and mices" (Birch, 1979) respectively, and its correlation with sales and employee growth. Why should we study these two types of SMEs? It is important because they contribute to economic development of a nation by creating most of jobs (Birch, 1979; Davidsson, P., L. Lindmark \& C. Olofsson, 1994; 1995; 1996; 1997; 1997; OECD, 1987; Magnus \& Johansson, 2010). Although these researches argue that gazelles create a "disproportionately" large number of new jobs comparing to mices, however, Neumark et al. (2008) have different view, arguing that mices have been classified as more jobs creators than it is reported. We believe that both of them are important and they are one of the most important pillars of economic growth of a state so we need to study them thoroughly.

Regarding the entrepreneurial orientation (EO), we can observe that for last three decades it has been studied using various measures for business performance of SMEs. A firm's upward growth could be related and connected to the entrepreneurship orientation (Brown et al., 2001; Stevenson \& Jarillo, 1990). This relationship phenomenon of EO and firm's growth or performance is comprehensively researching from the theory (Covin \& Slevin, 1991; Lumpkin \& Dess, 1996) and practice (Covin \& Slevin, 1989; Lumpkin \& Dess, 2001; Wiklund \& Shepherd, 2005). Despite this complete and extensive research there are some limitations and issues to be discussed. These are combined indicators, profitability and growth to associate with EO as sometimes contrary ones, and the developed latter concept of EO which is multidimensional (Moreno \& Casillas, 2008). Entrepreneurial orientation has a positive effect towards a firm's performance and it helps the firm to grow (Wiklund \& Shepherd, 2003). According to Kusumawardhani et al. (2009), he finds that SMEs with high level of EO have a better performance comparing to those who have a very low level of EO. However, on the other hand, Thomas and Mueller (2000) suggest that impact of EO to SMEs performance may differ from a country to a country. Depending to which part of the world a particular SME belongs it may happen that its adoption will vary. In this context Naldi et al. (2007) and Lee \& Peterson (2000) argue that "national culture" affects the way 
how the EO could be applied. Thus, each culture of a nation should be carefully observed in order to apply EO as a positive effect to SMEs performance. This model is widely used to measure and compare business performance of the companies and organizations.

Studying both gazelles and mices is important due to the fact that they create a positive economic growth in terms of reduction in unemployment rate. Economic development of Bosnia and Herzegovina is an imperative and its economy needs at first place "gazelles" to improve economic outlook in general. In this content, mices should not be neglected as well.

The objective of this study is to examine a presence of EO dimensions in Bosnian gazelles and mices, its correlation with their business performance and what might be associated with change in their business performance (sales growth and employee growth). We examine application of the theory of EO in gazelles and mices developed by Covin and Slevin (1989), and which was further studied and developed by (Lee et al., 2001; Wiklund \& Shepherd, 2005; Sue et al., 2011; Zhang \& Zhang, 2012; Kraus et al., 2012; Kraus, 2013).

In what follows, section 2 briefly reviews EO and the EO dimensions. The section 3 links such literature to specific empirical analysis using a certain methodology. In section 4 and 5, we discuss obtained empirical results and derive important conclusions, managerial implications and limitations of the research. Why is this problem important?

\section{EO Overview}

The first concept of entrepreneurial orientation started with Miller (1983) who has depicted a company as entrepreneurial if "one that engages in product market innovation, undertakes somewhat risky ventures, and is first to come up with proactive innovations, beating competitors to the punch". This idea support Covin and Slevin (1989). This basic idea on entrepreneurial orientation is also adopted by others like Lee and Peterson (2000); Kreiser et al. (2002); Wiklund (1999), while Lumpkin and Dess (1996), have adapt the first idea from Miller (1983) and Covin and Slevin (1989) by adding two additional dimensions, i.e. autonomy and competitive aggressiveness. This concept is developed and discussed through decades and the following sections try to overview in a concise way recent work done by researchers on this topic.

\subsection{Entrepreneurial Orientation Dimensions}

Miller (1983) argues that SMEs in order to grow and be sustainable it should be oriented towards the "product market innovation", which is followed by being a first in the market and ready to undertake the "risky ventures". Covin and Slevin (1989/1991) and Lumpkin and Dess (1996) suggest that an SME should not have administrative procedures that will prevent growth of the SME. In other words, the SME should have a leader with creativity that encourages innovation and eventually to "beat competitors to the punch" (Miller, 1983). His work supports Chow (2006) arguing that these three dimensions are unique and ample to affect SMEs performance, while Lumpkin and Dess (1996) and Hughes and Morgan (2007) argue that these additional dimensions, autonomy and competitor aggressiveness, are necessary because SMEs grow through different development stages. In a very similar way, Kreiser et al. (2002) argue that more options to improve SME's performance, the better chance for its improvement as additional two dimensions will provide. Lumpkin et al. (2009) confirm that the autonomy plays a strategic role in "in entrepreneurial value creation" and thus it should not be neglected. In the research done by Lee and Lim (2009), the EO proves its importance for services business. They argued that the EO is imperative to all SMEs' owners due to its positive effect. However, Su et al. (2011) find that there is a positive relationship between EO and firms' performance only for established firms and on the contrary it has inverse U-shaped curvature towards new ventures.

Lee and Peterson (2000) study EO in the light of culture based on the Hofstede (1980) and Trompenaars (1994) cultural dimensions. They show that a culture in its nature is "low on power distance, weak in uncertainty avoidance and masculine, while a culture which is "individualistic, achievement oriented and universalistic" will generate efficient EO. This kind of EO will be attributed "by autonomy, proactiveness, competitive aggressiveness, innovativeness, and risk taking". Such powerful EO is able to pave the way to powerful entrepreneurship and globally recognized competitive advantage. As such, a brief overview of EO dimensions is followed by next subsections.

\subsubsection{Innovativeness}

Another term for innovation is innovativeness which, according to Lumpkin \& Dess (1996), implies the propensity, creating new things, creativity in processes and experiments that leads to development of new products or services or even a new set of technological processes. Schumpeter (1942) gives a basis for this term arguing that innovative things combined together in the marketplace foster progress in particular society. 
However, what might be a little confusing is that innovation or innovativeness is not the same as inventiveness. Inventiveness is a part of the general process of innovation and it is not enough per se for an SME to be innovative firm. It needed in SMEs but not enough for the SMEs prosperity and sustainability (Trevis et al., 2009).

Innovativeness in its essence implies an intension to back up new ideas and approaches, novel things, experiments, innovative procedures and steps starting with the built principles and technologies (Lumpkin and Dess, 1996). In the study done by Tajeddini (2010), a positive relationship between the Innovativeness and business performance in the services sector was found.

\subsubsection{Proactiveness}

What makes a firm proactive? The proactive firm is always first entrants into a new market and they are the first or pioneer in that particular business (Trevis et al., 2009). To be first in the market an organization needs to be "first-mover" in the market providing possible offerings to the market that is based on the needs of customers (Lumpkin \& Dess, 1996). Once the firm has its advantage of being a "first-mover" then the firm has open the door to get advantage of this role by "skimming" pricing strategy possibly to be applied in such market (Zahra \& Covin, 1995). Similarly, it can become a market controller in monitoring "distributing chains" and it may welcome to establish "brand recognition" very quickly (Wiklund \& Shepherd, 2003).

\subsubsection{Risk-Taking}

Risk taking is related to the risk of turnover or to the risk of other financial analysis (Trevis et al., 2009) and anything that is huge action of let say, "borrowing" in capital and financial terms that might face the uncertainty could be regarded as risk taking (Baird \& Thomas, 1985). The risk could be perceived as a company's intention to be involved in lofty risk projects and managerial options opposite to prudent actions (Miller, 1983).

One may pose a question how to define when an entrepreneur is risk taker? It is complex since entrepreneurs do perceive these things differently. Recent research has argued that from entrepreneurs' perspective, their actions are not risky (Simon, Houghton, \& Aquino, 2000), and only action, to reduce the risk, is undertaken after planning and anticipating all circumstances (Bhide, 2000).

\subsection{Entrepreneurial Orientation (EO) Development and Performance}

As everything, the EO is evolving from time to time and applied in a different ways and to different organizations types.

The very beginning of EO started with Schumpeter (1942) who stresses out the importance of entrepreneurial orientation. The table 1 shows the EO chronological developments that lasted over three decades.

In regard of business performance that could be applied in the research of SME and EO related there are many measures that have been undertook. The "performance" itself might be measured in perceived financial terms, perceived non-financial and "archivical financials" or eventually to make any of possible combinations in the particular research (Rauch et al., 2009). In our study, similar to Kraus et al. (2012), we take perceived financial measures due to unavailability financial data of the companies in Bosnia and Herzegovina. Bamford et al. (2000, p. 255) consider this data as disadvantageous that may negatively affect results reliability. Others found that perceived financial rates are more less the same and in many cases.

Research undertaken by Lee and Lim (2009), show a positive relationships between EO and business performance of the services firms arguing that EO development among the SMEs' owners is a receipts for their growth and development. 
Table 1. Summary of EO development

\begin{tabular}{|c|c|c|c|}
\hline EO Dimensions & Author(s) & Year & Change(s) in EO \\
\hline Innovativeness & Miller & 1983 & \\
\hline \multicolumn{4}{|l|}{ Proactiveness } \\
\hline \multicolumn{4}{|l|}{ Risk-taking } \\
\hline Innovativeness & Covin and Slevin & $1989 / 1$ & No \\
\hline Proactiveness & & 991 & \\
\hline \multicolumn{4}{|l|}{ Risk-taking } \\
\hline $\begin{array}{l}\text { Environmental turbulence, entrepreneurial style, } \\
\text { organization structure, mission strategy }\end{array}$ & Naman and Slevin & 1993 & A normative model of fit \\
\hline Innovativeness & Lumpkin and Dess & 1996 & Two additional dimensions \\
\hline \multicolumn{4}{|l|}{ Proactiveness } \\
\hline \multicolumn{4}{|l|}{ Risk-taking } \\
\hline \multicolumn{4}{|l|}{ Autonomy } \\
\hline \multicolumn{4}{|l|}{ Competitor aggressiveness } \\
\hline Innovativeness & Wiklund & 1999 & No \\
\hline \multicolumn{4}{|l|}{ Proactiveness } \\
\hline \multicolumn{4}{|l|}{ Risk-taking } \\
\hline Innovativeness & Lee and Lim & 2009 & Supported Lumpkin and Dess \\
\hline \multicolumn{4}{|l|}{ Proactiveness } \\
\hline \multicolumn{4}{|l|}{ Risk-taking } \\
\hline \multicolumn{4}{|l|}{ Autonomy } \\
\hline \multicolumn{4}{|l|}{ Competitor aggressiveness } \\
\hline $\begin{array}{l}\text { Strategic decision-making participativeness } \\
\text { strategy formation mode }\end{array}$ & Covin, Green, Slevin & 2006 & A new approach of EO \\
\hline strategic learning from failure & & & \\
\hline $\begin{array}{l}\text { Innovativeness, } \quad \text { diligence, } \\
\text { self-confidence }\end{array}$ & Home & 2011 & A new approach of EO \\
\hline
\end{tabular}

Source: Author's compilation.

Table 2. Summary of overviewed EO dimensions and relationship with business performance

\begin{tabular}{|c|c|c|c|}
\hline Author & EO dimensions & $\begin{array}{l}\text { EO vs. } \\
\text { performance }\end{array}$ & Business \\
\hline Miller (1983) & Innovativeness, Proactiveness, Risk-taking & Positive & \\
\hline Covin and Slevin $(1988 ; 1989)$ & Innovativeness, Proactiveness, Risk-taking & Positive & \\
\hline Slater and Narver (2000) & $\begin{array}{l}\text { Environmental Turbulence, Entrepreneurial Style, Organization } \\
\text { Structure, Mission Strategy }\end{array}$ & Negative & \\
\hline Lee et al (2001) & Innovativeness, Proactiveness, Risk-Taking & Positive & \\
\hline Wiklund, Shepherd (2005) & Innovativeness, Proactiveness, Risk-Taking & Positive & \\
\hline Covin, Green, Slevin (2006) & $\begin{array}{l}\text { Strategic Decision-Making; Participativeness Strategy Formation } \\
\text { Mode; Strategic Learning From Failure; }\end{array}$ & Positive & \\
\hline Runyan et al (2008) & Innovativeness, Proactiveness, Risk-Taking; SBO & Positive & \\
\hline Lee and Lim (2009) & $\begin{array}{l}\text { Innovativeness; Proactiveness; Risk-Taking; Autonomy; } \\
\text { Competitor Aggressiveness }\end{array}$ & Positive & \\
\hline Li, Huang, Tsai & $\begin{array}{l}\text { Innovativeness; Proactiveness; Risk-Taking; Autonomy; } \\
\text { Competitor Aggressiveness }\end{array}$ & Positive & \\
\hline Tajeddini (2010) & Innovativeness & Positive & \\
\hline Casillas \& Moreno (2010) & $\begin{array}{l}\text { Innovativeness; Proactiveness; Risk-Taking; Autonomy; } \\
\text { Competitor Aggressiveness }\end{array}$ & Positive & \\
\hline Su et al (2011) & Innovativeness, Proactiveness, Risk-Taking & Positive & \\
\hline Zhang and Zhang (2012) & Innovativeness, Proactiveness, Risk-Taking & Positive & \\
\hline Kraus et al (2012) & Innovativeness, Proactiveness, Risk-Taking & Positive & \\
\hline Kraus (2013) & Innovativeness, Proactiveness, Risk-Taking & Positive & \\
\hline
\end{tabular}

Note. Su et al (2011): It is positive for established firms and not for new ventures. Kraus et al (2012): Positive only for proactiveness, innovativeness and risk taking has shown no positive relationships. Source: Author's compilation. 
Table 3. Summary of SMEs' business measures, sample size and industry

\begin{tabular}{|c|c|c|c|}
\hline Author & Performance/Growth Indicator(s) & $\begin{array}{l}\text { Sample } \\
\text { Size }\end{array}$ & Industry \\
\hline Miller (1983) & & - & \\
\hline $\begin{array}{l}\text { Covin and Slevin } \\
(1988 ; 1989)\end{array}$ & $\begin{array}{l}\text { Operating profits; profit to sales ratio; cash flow from operations; and } \\
\text { return on investment; Sales level, sales } \\
\text { growth rate, cash flow, return on shareholder } \\
\text { equity, gross profit margin, net profit from operations, profit to sales ratio, } \\
\text { return on investment, and ability to fund business growth from profits }\end{array}$ & $\begin{array}{l}80 \text { (1988); } \\
161 \text { (1989) }\end{array}$ & $\begin{array}{l}\text { Manufacturing } \\
\text { services firms }\end{array}$ \\
\hline $\begin{array}{l}\text { Slater and } \\
\text { Narver (2000) }\end{array}$ & ROI & 53 & $\begin{array}{l}\text { Manufacturing and } \\
\text { services firms }\end{array}$ \\
\hline Lee et al (2001) & Sales growth & 137 & Technological firms \\
\hline $\begin{array}{l}\text { Wiklund, } \\
\text { Shepherd (2005) }\end{array}$ & $\begin{array}{l}\text { Sales growth rate, employee growth, gross margin, profitability and cash } \\
\text { flow }\end{array}$ & 413 & $\begin{array}{l}\text { Manufacturing, services } \\
\text { and retail firms }\end{array}$ \\
\hline $\begin{array}{l}\text { Covin, Green, } \\
\text { Slevin (2006) }\end{array}$ & Sales growth & 110 & Manufacturing firms \\
\hline $\begin{array}{l}\text { Runyan et al } \\
(2008)\end{array}$ & "Overall performance" & 267 & $\begin{array}{l}\text { Manufacturing, services } \\
\text { and retail firms and } \\
\text { others }\end{array}$ \\
\hline $\begin{array}{l}\text { Lee and Lim } \\
(2009)\end{array}$ & Overall firm's performance & 137 & Services firms \\
\hline Li, Huang, Tsai & $\begin{array}{l}\text { Efficiency (return on investment, return on equity, and return on assets), } \\
\text { growth (sale growth, employee growth, and market share growth), and } \\
\text { profit (return on sales, net profit margin, and gross profit margin). }\end{array}$ & 165 & Unknown \\
\hline Tajeddini (2010) & Profit goal achievement; sales goal achievement; and ROI achievement & 156 & Services \\
\hline $\begin{array}{l}\text { Casillas \& } \\
\text { Moreno (2010) }\end{array}$ & Sales growth & 449 & Manufacturing, services \\
\hline Su et al (2011) & ROA;ROS; sales; net profit; market share & & \\
\hline $\begin{array}{l}\text { Zhang and } \\
\text { Zhang (2012) }\end{array}$ & $\begin{array}{l}\text { Perceived growth in market share; change in cash flow; sales growth; } \\
\text { earnings including the salary of the founder; sales; net worth. }\end{array}$ & 130 & Unknown \\
\hline $\begin{array}{lll}\text { Kraus } & \text { et } \quad \text { al } \\
(2012) & & \end{array}$ & Growth in a number of employees; growth in turnover; & 164 & Manufacturing, services \\
\hline Kraus (2013) & Sales growth, employment growth, and market share & 310 & Services \\
\hline
\end{tabular}

This table shows a relationship between EO dimensions and business performances (with different measurements) of SMEs with different business orientation (manufacturing, services, technology, retail/wholesale, and others). Most of them have been proved that EO dimensions had a positive relationship with business performance of firms. However, one of them has found a negative relationship between EO dimensions and business performance of firms (Slater \& Narver, 2000).

\section{Empirical Analysis}

\subsection{Data}

In this research we have used a self-administered questionnaire to collect data based on Covin and Slevin (1989) model. Its original version has been translated into Bosnian language and then reversed back to English. There were no inconsistencies that may affect the original model so it is preceded with Bosnian version of questionnaire. So the model of EO dimensions from Covin and Slevin (1989) is adopted and modified for the research. The 7-Likert opposite scale has been used, where 1 is strongly disagree and 7 is strongly agree.

In order to identify gazelles and mices we use Davidsson and Henrekson (2002) applying annual sales growth of 5 or $10 \%$, and Hölzl, W. (2009), seeing gazelles as companies whose annual employee growth are $10 \%$ with inconsistencies of $5 \%$.

Stratified sampling has been used. From the database of SMEs provided by Federal Ministry for Entrepreneurship, Development and Turnover and Foreign Trade Chamber of Bosnia and Herzegovina, which 
contain 16,480 SMEs, we randomly selected 5\% (in total 824 SMEs). We received 205 responses and 27 were rejected due to our stratification strategy that SMEs were identified as either gazelles or mices, we end with 178 SMEs which corresponds to $21,6 \%$. So, the effective sample size was 178 split up into two stratums, gazelles (89) and mices (89).

\section{Empirical Results}

\subsection{Factor Analysis}

We use factor analysis to check whether the data are fully loaded and to measure construct validity and its multidimensionality (Nunnally, 1978, Kraus et al., 2012). All independent variables, the EO dimensions, were loaded to perform these measurements. Principal component analysis (PCA) is applied to identify a path or a few paths that could explain their variability as much as possible (Belle et al., 2004, p. 589). We apply orthogonal and Varimax method. Orthogonal (unrelated) rotation is rotating factors with keeping all variables independent. Varimax method is good to minimize dispersion of loaded items within factors so that a smaller numbers of loaded variables will be loaded in a very high manner (Field, 2005, pp. 635-637). To determine number of loading factors we used the Kaiser Criterion that is set out as eigenvalues $>1$ (Kaiser, 1960). Factor loadings results may depend on sample size. Sevens (1992) argues that a sample size larger than 100 is to be as appropriate to get acceptable results as of 0.52 . Kaiser (1974) argues that any value greater than 0.5 is acceptable. The results have shown that we have three components and we maximized loadings on each variable of extracted factors while minimized loadings are on all other factors. Initial eigenvalues and extracted percentage of explained variances are the same, whereas factor 1 has higher value $(42,039 \%)$ comparing to the rest two $(17,69 \%$ and $11,55 \%$ respectively). After rotation of variables, the total $\%$ of explained variance was for factor $129,79 \%$, factor $229,23 \%$ and 12, 26\% of the factor 3 (See Table 4). Bertlett's test of sphericity applies control whether the PCA has a point to be set out and if p-value is less than 0.001. In our case it is significant ( $\mathrm{Sig}=.000)$. The $\mathrm{KMO}$ measure was obtained as 0.801 , with Chi-square of $638.035,(\mathrm{df}=36)$, which is more than required $(>0.5$, Kaiser, 1974), and it has proved sampling adequacy.

Table 4. Total variance explained for eigenvales, extraction and rotation loadings

\begin{tabular}{|c|c|c|c|c|c|c|c|c|c|}
\hline \multirow[b]{2}{*}{ Component } & \multicolumn{3}{|c|}{ Initial Eigenvalues } & \multicolumn{3}{|c|}{ Extraction Sums of Squared Loadings } & \multicolumn{3}{|c|}{ Rotation Sums of Squared Loadings } \\
\hline & Total & $\begin{array}{l}\% \text { of } \\
\text { Variance }\end{array}$ & $\begin{array}{l}\text { Cumulative } \\
\%\end{array}$ & Total & $\begin{array}{ll}\% & \text { of } \\
\text { Variance } & \\
\end{array}$ & $\begin{array}{l}\text { Cumulativ } \\
\text { e \% }\end{array}$ & Total & $\begin{array}{ll}\% & \text { of } \\
\text { Variance } & \\
\end{array}$ & $\begin{array}{l}\text { Cumulative } \\
\%\end{array}$ \\
\hline 1 & 3.783 & 42.039 & 42.039 & 3.783 & 42.039 & 42.039 & 2.682 & 29.795 & 29.795 \\
\hline 2 & 1.593 & 17.696 & 59.734 & 1.593 & 17.696 & 59.734 & 2.631 & 29.230 & 59.025 \\
\hline 3 & 1.040 & 11.55 & 71.285 & 1.040 & 11.550 & 71.285 & 1.103 & 12.260 & 71.285 \\
\hline 4 & 0.693 & 7.702 & 78.986 & & & & & & \\
\hline 5 & 0.563 & 6.253 & 85.240 & & & & & & \\
\hline 6 & 0.447 & 4.963 & 90.202 & & & & & & \\
\hline 7 & 0.400 & 4.446 & 94.648 & & & & & & \\
\hline 8 & 0.263 & 2.924 & 97.573 & & & & & & \\
\hline 9 & 0.218 & 2.427 & 100.000 & & & & & & \\
\hline
\end{tabular}

The eigenvalues set (eigenvalues $>1$; Kaiser, 1960) shows the same results as Scree plot (Fig 1), meaning that the inflexion on the Scree plot confirmed extraction of 3 components. 


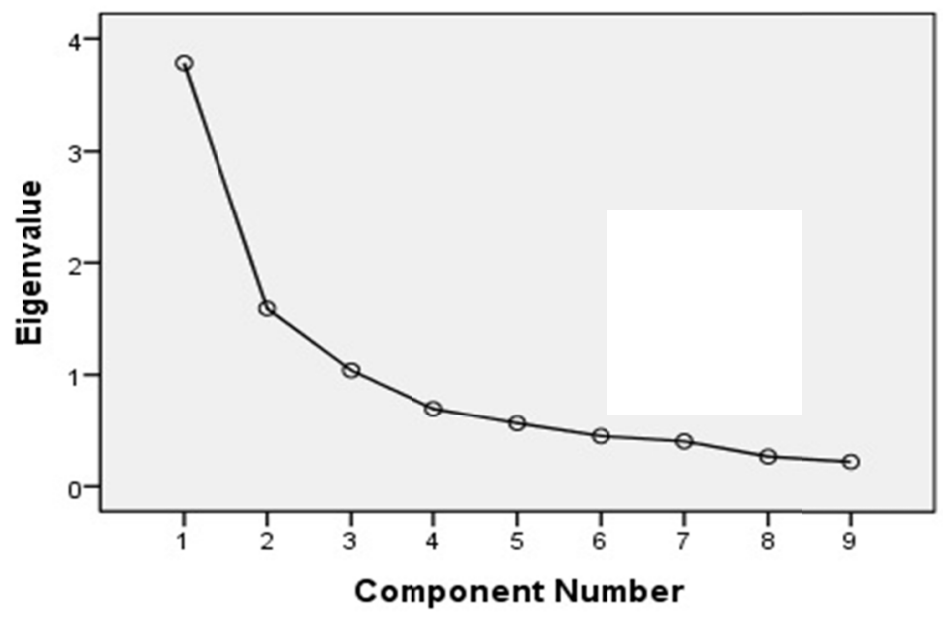

Figure 1. Scree plot: the number of components

\subsection{Data Reliability-Cronbach's Alpha}

This research is built on the EO, defined and developed by Covin and Slevin (1989), and adopted as such; we may not go through the validity analysis for systematic errors (Lee \& Lim, 2009). However, we still need to make sure for the survey designed that is consistently valid. In this regard we used the Cronbach's alpha values that measures internal consistency and internal reliability of the sample that is used, which will give us a relationship(s) between the tested items of the research. Hair et al. (1998/2006), Bagozzi \& Yi (1988), Baker et al. (2002), Nunnally (1978) suggest a minimum value for the Cronbach's alpha to be accepted as 0.6-0.7. In this case Cronbach's alpha value is 0.806 which satisfies condition for its data reliability.

The result is moderate with its reliability of 0.806 and only 0.194 contains errors (Table 5), i.e. $80.6 \%$ of the test is reliable and $19.4 \%$ of it is unreliable. The loadings of variables were according to hypotheses that suppose to be tested. In this context there were in total 11 items loaded, 9 predictor variables and 2 criterion variables.

\subsection{Control Variable}

Regarding relationship between EO dimensions and performance, additional independent variable might be associated with firm's performance. This variable is called control variable. We use firm age to perform regression analysis that will confirm or reject its association with business performance along with EO dimensions of both gazelles and mices $\left(\mathrm{H}_{1 \mathrm{~d}}\right)$.

\subsection{Hypotheses}

Testing hypotheses is built on the following:

$\mathrm{H}_{0}$ : Entrepreneurial orientation dimensions are less present in "gazelles" companies while more present in "mices" companies and EO dimensions have no a significant relationship with their business performance and growth in Bosnia and Herzegovina.

$\mathrm{H}_{1}$. Entrepreneurial orientation dimensions are more present in "gazelles" companies while less present in "mices" companies and EO dimensions have a significant relationship with their business performance and growth in Bosnia and Herzegovina.

$\mathrm{H}_{1 \mathrm{a}}$. Innovation is more present in "gazelles" while it is less present in "mices".

$\mathrm{H}_{1 b}$. Proactiveness is more present in "gazelles" while it is less present in "mices".

$\mathrm{H}_{1 \mathrm{c}}$. Risk taking is more present in "gazelles" companies while it is less present in "mices".

$\mathrm{H}_{1 \mathrm{~d}}$. EO dimensions have a significant correlation and relationship with business performance and growth of gazelles and mices in Bosnia and Herzegovina.

Table 5 shows that overall EO dimensions are more present in gazelles than in mices. Presence of innovation in gazelles is 4.978 while in mices 4.270. Proactiveness is scored 5.596 comparing to mices 4.427. And risk taking score is also higher in gazelles than in mices (4.640 vs. 4.067). T-test (Table 6) shows its significance at all levels of $(t=3,420, \operatorname{Sig}=0.001 ; t=2,750, \mathrm{Sig}=0.007)$ except for proactiveness $(t=0.760 ; \mathrm{Sig}=0.448)$. The score results of proactiveness in gazelles is higher comparing to mices' score, however, $t$-test has shown insignificant $(\mathrm{p}>0.05)$. 
The highest score of EO dimensions in gazelles is for innovation, while the least one is for proactiveness. In mices firms, the highest score is from proactiveness too, while the poorest score is on risk taking dimension as well (Table 5).

Table 5. Comparison of means for gazelles and mices

\begin{tabular}{llllll}
\hline EO dimensions & SMEs & $\mathrm{N}$ & Mean & Std. Deviation & Std. Error Mean \\
\hline \multirow{2}{*}{ INNOVATION } & Gazelles & 89 & 4.978 & 1.3398 & .1420 \\
& Mices & 89 & 4.270 & 1.4203 & .1506 \\
\multirow{2}{*}{ PROACTIVENES } & Gazelles & 89 & 4.596 & 1.4438 & .1530 \\
& Mices & 89 & 4.427 & 1.5142 & .1605 \\
\multirow{2}{*}{ RISK TAKING } & Gazelles & 89 & 4.640 & 1.0686 & .1133 \\
& Mices & 89 & 4.067 & 1.6501 & .1749 \\
\hline
\end{tabular}

Table 6. T-Test values results

\begin{tabular}{|c|c|c|c|c|c|c|c|c|}
\hline & & & & & & & \multicolumn{2}{|c|}{$\begin{array}{l}95 \% \text { Confidence interval of the } \\
\text { Difference }\end{array}$} \\
\hline & & $\mathrm{t}$ & $\mathrm{df}$ & $\begin{array}{l}\text { Sig. } \\
\text { (2-tailed) }\end{array}$ & $\begin{array}{l}\text { Mean } \\
\text { Difference }\end{array}$ & $\begin{array}{l}\text { Std. Error } \\
\text { Difference }\end{array}$ & Lower & Upper \\
\hline \multirow{2}{*}{ Innovation } & $\begin{array}{l}\text { Equal variances } \\
\text { assumed }\end{array}$ & 3.42 & 176 & 0.001 & 0.7079 & 0.207 & 0.2294 & 1.1163 \\
\hline & $\begin{array}{l}\text { Equal variances } \\
\text { not assumed }\end{array}$ & 3.42 & 175.403 & 0.001 & 0.7079 & 0.207 & 0.2294 & 1.1163 \\
\hline \multirow{2}{*}{ Proactiveness } & $\begin{array}{l}\text { Equal variances } \\
\text { assumed }\end{array}$ & 0.76 & 176 & 0.448 & 0.1685 & 0.2218 & -0.2691 & 0.6062 \\
\hline & $\begin{array}{l}\text { Equal variances } \\
\text { not assumed }\end{array}$ & 0.76 & 175.602 & 0.448 & 0.1685 & 0.2218 & -0.2691 & 0.6062 \\
\hline \multirow{2}{*}{ Risk Taking } & $\begin{array}{l}\text { Equal variances } \\
\text { assumed }\end{array}$ & 2.75 & 176 & 0.007 & 0.573 & 0.2084 & 0.1618 & 0.9843 \\
\hline & $\begin{array}{l}\text { Equal variances } \\
\text { not assumed }\end{array}$ & 2.75 & 150.776 & 0.007 & 0.573 & 0.2084 & 0.1618 & 0.9843 \\
\hline
\end{tabular}

To confirm the previous result and get decision rule (if $\mathrm{p}<0.05$, reject $\mathrm{H}_{0}$ ) on $\mathrm{H} 0$ and $\mathrm{H}_{1}$, we use the $\mathrm{t}$-test. The $\mathrm{t}$-values with its degree of freedom $(\mathrm{df}=176)$ for two EO dimensions are high for two predictors resulting in its significance, $\mathrm{Sig}=0.001 ; 0.007$ respectively, (innovation, risk-taking) confirmed that H0 is rejected, confirming $\mathrm{H}_{1}\left(\mathrm{H}_{1 \mathrm{a}}\right.$ and $\left.\mathrm{H}_{1 \mathrm{c}}\right)$. Moreover, although the total score of mean for proactiveness is higher in comparison to one in mices, the t-test do not reject and $\mathrm{HOb}(\mathrm{p}>0.05)$ and $\mathrm{H}_{1 \mathrm{~b}}$ is not supported (Table 6).

Correlation matrix has shown the possible correlation between predicted and criterion variables. In this case predicted variables are innovation, proactiveness, risk taking while criterion variables (dependent) are sales and employee growth over last 3 years or less if a firm exists less than 3 years. Results are reported in the Table 7. Proactiveness, among the rest EO dimensions, has no positive correlation with sales growth (0.057) but not significant $(p>0.05)$. The same is true for correlation between proactiveness and employee growth $(0.061$; $\mathrm{p}>0.05$ ). Innovation has significantly positive correlation with sales growth (almost moderate correlation with $0.250, \mathrm{p}<0.001$ ) while its correlation with employee growth have also moderate correlation value of 0.296 and yet significant $(p<0.001)$. Risk-taking has lower correlation coefficients with sales growth $(0.203 ; p<0.007)$ and employee growth $(0.228 ; \mathrm{p}<0.002)$. So, $\mathrm{H}_{1 \mathrm{~d}}$ is partially supported (innovation and risk taking have positive correlation with sales and employee growth). 
Table 7. Correlation matrix results

\begin{tabular}{|c|c|c|c|c|c|c|}
\hline & & Sales Growth & Employee Growth & Innovation & Proactiveness & Risk Taking \\
\hline \multirow[t]{3}{*}{ Sales Growth } & Pearson Correlation & 1 & & & & \\
\hline & Sig.(2-tailed) & & & & & \\
\hline & $\mathrm{N}$ & 178 & & & & \\
\hline \multirow[t]{3}{*}{ Employee Growth } & Pearson Correlation & $.756^{* *}$ & 1 & & & \\
\hline & Sig.(2-tailed) & 0.000 & & & & \\
\hline & $\mathrm{N}$ & 178 & 178 & & & \\
\hline \multirow[t]{3}{*}{ Innovation } & Pearson Correlation & $.250 * *$ & $.296 * *$ & 1 & & \\
\hline & Sig.(2-tailed) & 0.001 & 0.000 & & & \\
\hline & $\mathrm{N}$ & 178.000 & 178 & 178 & & \\
\hline \multirow[t]{3}{*}{ Proactiveness } & Pearson Correlation & 0.057 & 0.061 & $.471 * *$ & 1 & \\
\hline & Sig.(2-tailed) & 0.448 & 0.420 & 0.000 & & \\
\hline & $\mathrm{N}$ & 178 & 178 & 178 & 178 & \\
\hline \multirow[t]{3}{*}{ Risk Taking } & Pearson Correlation & $.203 * *$ & $.228 * *$ & $.255^{* *}$ & $.364 * *$ & 1 \\
\hline & Sig.(2-tailed) & 0.007 & 0.001 & 0.001 & 0.000 & \\
\hline & $\mathrm{N}$ & 178 & 178 & 178 & 178 & 178 \\
\hline
\end{tabular}

These results reject $\mathrm{H}_{0 \mathrm{~d}}$ and support $\mathrm{H}_{1 \mathrm{~d}}$. Since we have partially confirmed hypotheses that we tested, we want to see how much of predictor variables could be explained in criterion variables. We use linear regression to create a combination that will fit the regression model. In this case we had 2 criterion variables, sales and employee growth and three predicted variables, innovation, proactiveness and risk-taking. Controlling variable is firm age of firms.

\section{Criterion 1: Sales growth}

Linear regression was used to examine whether EO dimensions (innovation, proactiveness, risk-taking) and together with control variables (firm type, firm age and firm size) significantly predict relationship with sales growth and employee growth rate over last three years. Two models were setup. In the first model we include innovation, proactiveness and risk-taking as independent variables. In the second model we add firm age. Firm age was added to second model.

The null hypothesis: $\boldsymbol{H}_{\boldsymbol{d} \boldsymbol{d}}=\beta_{1}=\beta_{2}=\beta_{3}=\beta_{4}$; EO dimensions do not have a significant relationship with business performance and growth of gazelles and mices in Bosnia and Herzegovina

Alternative hypotheses: $\boldsymbol{H}_{1 d}: \beta_{j} \neq 0$; for at least one of $j$, where $j=1,2,3 \ldots n$; EO dimensions have a significant relationship with business performance and growth of gazelles and mices in Bosnia and Herzegovina.

First model (Table 8) made of predictor variables, innovation, proactiveness and risk taking we have got $R^{2}$ change of 0.096 . So $9.6 \%$ variability has been counted by these EO dimensions. For model 2, along with EO dimensions, we added firm age as additional predictor variable, and results have shown that there is a slight increase in $R^{2}=0.136$ with a change of 0.040 or $4 \%$ of its variability.

Table 8. Regression model summary of results of 4 models: criterion 1 (sales growth)

\begin{tabular}{|c|c|c|c|c|c|c|c|c|c|c|c|c|}
\hline \multirow[b]{2}{*}{ Model } & \multirow[b]{2}{*}{$\mathrm{R}$} & \multirow[b]{2}{*}{$\begin{array}{l}\mathrm{R} \\
\text { Square }\end{array}$} & \multirow[b]{2}{*}{$\begin{array}{l}\text { Adjusted } \\
\text { Square }\end{array}$} & \multirow{2}{*}{$\mathrm{R}$} & \multirow[b]{2}{*}{$\begin{array}{l}\text { Std. Error } \\
\text { Estimate }\end{array}$} & \multicolumn{7}{|c|}{ Change Statistics } \\
\hline & & & & & & $\begin{array}{l}\mathrm{R} \\
\text { change }\end{array}$ & Square & $\begin{array}{l}\mathrm{F} \\
\text { change }\end{array}$ & df1 & df 2 & $\begin{array}{l}\text { Sig. } \\
\text { Change } \\
\end{array}$ & $\mathrm{F}$ \\
\hline 1 & $.310^{\mathrm{a}}$ & .096 & .081 & & .4808 & .096 & & 6.176 & 3 & 174 & .001 & \\
\hline 2 & $.36^{\mathrm{b}}$ & .136 & .116 & & .4713 & .040 & & 8.027 & 1 & 173 & .005 & \\
\hline
\end{tabular}

Note. a. Predictors: (constant), risk taking, innovation, proactivenes.

b. Predictors: (constant), risk taking, innovation, proactivenes, firm age.

c. Dependent variable: sales growth. 
Table 9. ANOVA results for criterion 1 sales growth

\begin{tabular}{lllllll}
\hline Model & & Sum of Squares & df & Mean Square & F & Sig. \\
\hline 1 & Regression & 4.282 & 3 & 1.427 & 6.176 & $.001^{\mathrm{b}}$ \\
& Residual & 40.218 & 174 & .231 & & \\
& Total & 44.500 & 177 & & & $.000^{\mathrm{c}}$ \\
& Regression & 6.066 & 4 & 1.516 & 6.826 & \\
& Residual & 38.434 & 173 & & & \\
& Total & 44.500 & 177 & & & \\
& & &
\end{tabular}

Note. a. Dependent variable: sales growth.

b. Predictors: (constant), risk taking, innovation, proactivenes.

c. Predictors: (constant), risk taking, innovation, proactivenes, firm age.

The ANOVA table (Table 9) results shown that the all variables in its aggregate for 2 models were significant predictors (independent variables along with control variable) of sales growth, whereas explaining $8.1 \%$ of the variation in the model $1, F(3,174)=6.176, p=.001$. In the model 2 , they explain $11.6 \%$ of their variability, $F(4$, $173)=8.027, p=.005$. These results imply rejection of the null hypothesis that says "EO dimensions do not have a significant relationship with business performance and growth of gazelles and mices in Bosnia and Herzegovina".

Results of linear regression models are shown in the table 11.

The following equation presents the general linear regression model:

$$
Y_{i}=\beta_{0}+\beta_{1}\left(X_{i 1}\right)+\cdots+\beta_{n} X_{n}+\varepsilon_{i}
$$

where, $Y_{i}$ is criterion variable (dependent variable), $\beta_{0}$ is constant where the $Y$ axis is intercepted by regression line; $\beta_{1}$ and $\beta_{\mathrm{n}}$ are the coefficients of the slope for regression predictors; $X_{\mathrm{i} 1}$ and $X_{\mathrm{n}}$ are the values of predictors values (independent variables) for some of $\mathrm{i}$ 'th observation; $\varepsilon_{\mathrm{i}}$ is residual.

In this context we have model 1:

$$
\text { Sales growth }=\beta_{0}+\beta_{1} \text { Innovation }+\beta_{2} \text { Proactiveness }+\beta_{3} \text { Risk_taking }+\varepsilon_{i}
$$

Model 2:

$$
\text { Sales growth }=\beta_{0}+\beta_{1} \text { Innovation }+\beta_{2} \text { Proactiveness }+\beta_{3} \text { Risk_taking }+\beta_{4} \text { Firm_age }+\varepsilon_{i}
$$

In terms of contribution of each predictor variable as well as control variable that is examined in 2 models, it shows that in two models, innovation, risk taking and the firm age are significant. Only, EO proactiveness is not significant. So independent variables (innovation and risk-taking) along with control variable (firm age), make a significant contribution to the models and therefore they were significant predictors of sales growth (Table10).

These results imply rejection of the null hypothesis that says "EO dimensions do not have a significant

\begin{tabular}{|c|c|c|c|c|c|c|c|c|}
\hline & & \multicolumn{2}{|c|}{ Unstandardized Coefficients } & \multicolumn{3}{|c|}{$\begin{array}{l}\text { Standardized } \\
\text { Coefficients }\end{array}$} & \multicolumn{2}{|c|}{$\begin{array}{l}95 \% \text { Confidence interval } \\
\text { for B }\end{array}$} \\
\hline \multirow[t]{2}{*}{ Model } & & $\mathrm{B}$ & Std. Error & Beta & t & $\mathrm{Si}$ & Lower & Upper \\
\hline & & & & & l & $\mathrm{s}$ & Bound & Bound \\
\hline \multirow[t]{4}{*}{1} & (Constant) & 1.988 & .154 & & 12.901 & .000 & 1.684 & 2.293 \\
\hline & Innovation & .094 & .029 & .267 & 3.246 & .001 & .037 & .151 \\
\hline & Proactives & -.046 & .029 & -.136 & -1.590 & .114 & -.103 & .011 \\
\hline & Risk Taking & .065 & .028 & .184 & 2.371 & .019 & .011 & .120 \\
\hline \multirow[t]{5}{*}{2} & (Constant) & -10.817 & 4.522 & & -2.392 & .018 & -19.742 & -1.891 \\
\hline & Innovation & .099 & .028 & .281 & 3.488 & .001 & .043 & .155 \\
\hline & Proactives & -.051 & .028 & -.151 & -1.804 & .073 & -.107 & .005 \\
\hline & Risk Taking & .065 & .027 & .184 & 2.411 & .017 & .012 & .118 \\
\hline & Firm Age & .006 & .002 & .201 & 2.833 & .005 & .002 & .011 \\
\hline
\end{tabular}
relationship with business performance and growth of gazelles and mices in Bosnia and Herzegovina".

Table 10. Beta coefficients and t-statistics summary: criterion 1 (sales growth) 


\section{Criterion 2: Employee growth}

Linear regression models for criterion 2 - employee growth are:

Model 1:

$$
\text { Employee growth }=\beta_{0}+\beta_{1} \text { Innovation }+\beta_{2} \text { Proactiveness }+\beta_{3} \text { Risk_taking }+\varepsilon_{i}
$$

Model 2:

Employee growth $=\beta_{0}+\beta_{1}$ Innovation $+\beta_{2}$ Proactiveness $+\beta_{3}$ Risk_taking $+\beta_{4}$ Firm_age $+\varepsilon_{i}$

Beta coefficients and t-statistics table (Table 10) show that prediction of criterion variable could be found in the model 1 and model 2. First model shows its significance in contribution of all three EO dimensions to employee growth. When we add control variable, the firm age, to EO dimensions, it does not significantly contribute to change in employee growth. On the contrary, other independent variables (innovation, proactiveness and risk-taking) show significance for variability in employee growth.

Results of the second criterion, employee growth, are shown in the table 11. Two models we develop and in the first model are the following predictor variables, innovation, proactiveness and risk taking. The $R^{2}(0.132), 13.2 \%$ of has been counted by these EO dimensions. For model 2 we add to EO dimensions the firm age as additional predictor variable, and results have shown that there is a little change in $R^{2}(0.145)$ of $0.013 \%(1,3 \%)$.

The ANOVA (Table 12) results shown that overall 2 models were significant predictors of employee growth, whereas explaining $11.7 \%$ of the variance in the model $1, F(3,174)=8.849, p=.000$. In the model 2 , they explain $12.5 \%$ of their variability, $F(4,173)=7.344, p=.000$.

Table 11. Regression model summary of results of 4 models: criterion 2 (employee growth)

\begin{tabular}{|c|c|c|c|c|c|c|c|c|c|c|c|c|}
\hline \multirow[b]{2}{*}{ Model } & \multirow[b]{2}{*}{$\mathrm{R}$} & \multirow[b]{2}{*}{$\begin{array}{l}\mathrm{R} \\
\text { Square }\end{array}$} & \multirow[b]{2}{*}{$\begin{array}{l}\text { Adjusted } \\
\text { Square }\end{array}$} & \multirow{2}{*}{$\mathrm{R}$} & \multirow[b]{2}{*}{$\begin{array}{l}\text { Std. Error } \\
\text { Estimate }\end{array}$} & \multicolumn{7}{|c|}{ Change Statistics } \\
\hline & & & & & & $\begin{array}{l}\mathrm{R} \\
\text { change }\end{array}$ & Square & $\begin{array}{l}\mathrm{F} \\
\text { change }\end{array}$ & df1 & df2 & $\begin{array}{l}\text { Sig. } \\
\text { Change }\end{array}$ & $\mathrm{F}$ \\
\hline 1 & $.364^{\mathrm{a}}$ & .132 & .117 & & 1.0571 & .132 & & 8.849 & 3 & 174 & .000 & \\
\hline 2 & $.381^{\mathrm{b}}$ & .145 & .125 & & 1.0523 & .013 & & 2.588 & 1 & 173 & .109 & \\
\hline
\end{tabular}

Note. a. Predictors: (constant), risk taking, innovation, proactivenes.

b. Predictors: (constant), risk taking, innovation, proactivenes, firm age.

Table 12. ANOVA results for criterion 2 employee growth

\begin{tabular}{lllllll}
\hline Model & & Sum of Squares & df & Mean Square & F & Sig. \\
\hline 1 & Regression & 29.666 & 3 & 9.889 & 8.849 & $.001^{\mathrm{b}}$ \\
& Residual & 194.452 & 174 & 1.118 & & \\
& Total & 224.118 & 177 & & & $.000^{\mathrm{c}}$ \\
2 & Regression & 32.533 & 4 & 8.133 & 7.344 & \\
& Residual & 191.585 & 173 & & & \\
& Total & 224.118 & 177 & & & \\
\end{tabular}

Note. a. Dependent variable: sales growth.

b. Predictors: (constant), risk taking, innovation, proactivenes.

c. Predictors: (constant), risk taking, innovation, proactivenes, firm age. 
Table 13. Beta coefficients and t-statistics summary: criterion 2 (employee growth)

\begin{tabular}{lllllllll}
\hline & & \multicolumn{2}{l}{ Unstandardized Coefficients } & \multicolumn{2}{l}{ Standardized Coefficients } & \multicolumn{3}{c}{ 95\% Confidence interval for B } \\
\hline Model & & $\mathrm{B}$ & Std. Error & Beta & $\mathrm{t}$ & Sig. & Lower Bound & Upper Bound \\
\hline 1 & (Constant) & .481 & .339 & & 1.419 & .158 & -.188 & 1.150 \\
& Innovation & .255 & .064 & .322 & 3.996 & .000 & .129 & .380 \\
& Proactives & -.127 & .064 & -.166 & -1.99 & .048 & -.252 & -.001 \\
& Risk Taking & .164 & .061 & .207 & 2.716 &. .007 & .045 & .284 \\
2 & (Constant) & -15.754 & 10.096 & & -1.56 & .121 & 35.682 & 4.174 \\
& Innovation & .261 & .064 & .330 & 4.111 & .000 & .136 & .387 \\
& Proactives & -.133 & .063 & -.175 & -2.10 & .037 & -.258 & -.008 \\
& Risk Taking & .164 & .060 & .207 & 2.723 & .007 & .045 & .283 \\
& Firm Age & .008 & .005 & .113 & 1.609 & .109 & -.002 & .018 \\
\hline
\end{tabular}

The table 13 shows coefficients of the two models of the criterion 2 (employee growth) with their corresponding values of $t$. The two models with EO dimensions have contribution to variability in change of employee growth, while adding the control variable firm age, does not contribute to its change as it is shown in the model 2.

The following table (Table 14) reviews developed hypotheses and their outcomes.

Table 14. Hypotheses testing results

\begin{tabular}{ll}
\hline Hypotheses & Results \\
\hline H1. Entrepreneurial orientation dimensions are more present in "gazelles" companies while less present in & Partially supported \\
"mices" companies and EO dimensions have a significant relationship with their business performance and & \\
growth in Bosnia and Herzegovina. & Supported \\
H1a. Innovation is more present in "gazelles" while it is less present in "mices". & Not supported \\
H1b. Proactiveness is more present in "gazelles" while it is less present in "mices". & Supported \\
H1c. Risk taking is more present in "gazelles" companies while it is less present in "mices". & Supported \\
H1d. EO dimensions have a significant correlation and relationship with business performance and growth of \\
gazelles and mices in Bosnia and Herzegovina.
\end{tabular}

\section{Conclusion}

The research on gazelles and mices (Birch, 1979) is done on EO theory framework developed by Covin and Slevin (1989). It analyses several hypotheses. First hypothesis states that "Entrepreneurial orientation dimensions are more present in "gazelles" companies while less present in "mices" companies and EO dimensions have a significant relationship with their business performance and growth in Bosnia and Herzegovina". Empirical results have shown that EO dimensions are more present in gazelles than in mices except proactivenes. This might be due to unwillingness of business owners and managers to take their moves ahead comparing to others. It is been proved that gazelles had more weight in terms of EO dimension comparing to mices (See Table 6). Correlation analysis shown significant low to moderate correlations between independent variables (innovation and risk taking) and dependent variables (sales growth and employee growth), while proactiveness did not show any correlation towards sales growth and employee growth. Similarly, in overall the "EO dimensions along with firms' age factor contribute to changes in sales and employee growth of both gazelles and mices" (Table 14).

In criterion 1, the sales growth, among predictor variables, only proactiveness has not been observed as significant in both models, while innovation and risk taking, accompanied with firm age, predicted variability and change in sales growth. In criterion 2, it was observed that EO dimensions had contributed to a change of employee growth. However, the firm age, has not bring any contribution in change of the employee growth.

Our results suggest that SMEs which want to have a significant business growth and develop faster (to become gazelles) they should incorporate innovation, proactiveness and risk taking. In addition, firm age of a SME gives more opportunity to achieve better business performance results. Meaning that, business owners and managers should look forward to be innovative, and when necessary risk-taking roles in the company.

Due to reluctance of the participants this research is lacking of a decent sample size $(n=178)$. In addition, achieved data for dependent variables, are known as perceived financial data that cannot predict eventual 
causality between dependent and independent variables. Also, "perceived financials", might be too subjective which also may reflect in the end results. Aforementioned limitations should be first task done for the same research. Also, we strongly suggest qualitative data that will support or reject objectives and hypotheses.

\section{Acknowledgement}

We would like to thank Dr. Ismir Mulalic from Technical University of Denmark for his very useful suggestions and comments during this research.

\section{References}

Bagozzi, R. P., \& Yi, Y. (1988). On the evaluation of structural evaluation models. Journal of the Academy of Marketing Science, 16(1), 74-94. http://dx.doi.org/10.1177/009207038801600107

Baker, J., Parasuraman, A., Grewal, D., \& Voss, G. B. (2002). The influence of multiple store environment cues on perceived merchandise value and patronage intentions. Journal of Marketing, 66(2), 120-141. http://dx.doi.org/10.1509/jmkg.66.2.120.18470

Baum, J. R., Dean, T. J., \& McDougale, P. P. (2000). An Examination of the Impact of Initial Founding Conditions and Decisions upon the Performance of New Bank Start Ups. Journal of Business Venturing, 15, 253-277.http://dx.doi.org/10.1016/S0883-9026(98)00011-1

Belle, G. V., Fisher L. D., Heagerty, P. J., \& Lumley, T. S. (2004). Biostatistics: A Methodology for the Health Sciences (2nd ed.). John Wiley \& Sons, Inc.

Carton, R. B., \& Hofer, C. W. (2006). Measuring Organizational Performance-Metrics for Entrepreneurship and Strategic Management Research. Cheltenham: Edward Elgar.

Casillas, C. J., \& Moreno, M. A. (2010). The Relationship between Entrepreneurial Orientation and Growth: The Moderating Role of Family Involvement. Entrepreneurship \& Regional Development: An International Journal, 22(3-4), 265-291. http://dx.doi.org/10.1080/08985621003726135

Chow, I. H. S. (2006). The Relationship between Entrepreneurial Orientation and Firm Performance in China. SAM Advanced Management Journal, 71(1), 1-20.

Covin, J. G., \& Slevin, D. P. (1991). A Conceptual Model of Entrepreneurship As Firm Behavior. Entrepreneurship. The OlY and Practice, 16, 7-25.

Covin, G. J., Green, K. M., \& Slevin, P. D. (2006). Strategic Process Effects on the Entrepreneurial Orientation-Sales Growth Rate Relationship. Entrepreneurship Theory and Practice, 30(1). http://dx.doi.org/10.1111/j.1540-6520.2006.00110.x

Davidsson, P., \& Henrekson, M. (2002). Determinants of the Prevalance of Start-ups and High-Growth Firms. Small Business Economics, 19(2), 81-104.

Davidsson, P., \& Delmar, F. (1997). High-growth firms: characteristics, job contribution and method observations. In RENT XI Conference, Mannheim, Germany.

Davidsson, P., Lindmark, L., \& Olofsson, C. (1994). Dynamiken i svenskt näringsliv (Business Dynamics in Sweden). Lund: Studentlitteratur.

Davidsson, P., Lindmark, L., \& Olofsson, C. (1995). The trend towards smaller scale during the 1980's: empirical evidence from Sweden. Paper presented at ICSB's 40th World Conference, Sydney.

Davidsson, P., Lindmark, L., \& Olofsson, C. (1996). Näringslivsdynamik under 90-talet (Business Dynamics in the '90s). Stockholm: NUTEK.

Davidsson, P., Lindmark, L., \& Olofsson, C. (1997a). The extent of overestimation in small firm job creation - an empirical examination of the regression bias. Small Business Economics.

Davidsson, P., Lindmark, L., \& Olofsson, C. (1997b). SMEs and job creation during a recession and recovery'. In Z. Acs, B. Carlsson and C. Karlsson (Eds.), SMEs, Entrepreneurship, and the Macro Economy. Cambridge University Press.

Delmar, F. (1997). Measuring growth: Methodological considerations and empirical problems. In Donckels R, Miettinen, A. (Ed.), Entrepreneurship and SME research: On its way to the next millennium (pp. 199-215). Andover, Ashgate.

Eurostat OECD. (2007). Eurostat-OECD manual on business demography statistics: European Communities/OECD. 
Field, A. (2005). Discovering statistics using SPSS (and sex and drugs and rock ' $n$ ' roll): ISM Introducing Statistical Methods. London: SAGE Publications.

Henrekson, M., \& Johansson, D. (2009). Gazelles as job creators: a survey and interpretation of the evidence. Small Business Economics. http://dx.doi.org/10.2139/ssrn.1092938

Henrekson, M., \& Johansson, D. (2010). Gazelles as job creators: a survey and interpretation of the evidence. Small Bus Econ, 35, 227-244. http://dx.doi.org/10.1007/s11187-009-9172-z

Hölzl, W. (2009). Is the R\&D behaviour of fast-growing SMEs different? Evidence from CIS III data for 16 countries. Small Business Economics, 33(1), 59-75. http://dx.doi.org/10.1007/s11187-009-9182-x

Hofstede, G. (1980). Culture's consequences: International differences in work-related values. Beverly Hills, CA: Sage.

Home, N. (2011). Entrepreneurial orientation of grocery retailers in Finland. Journal of Retailing and Consumer Services, 18, 293-301. http://dx.doi.org/10.1016/j.jretconser.2011.02.003

Hughes, M., \& Morgan, R. E. (2007). Deconstructing the Relationship between Entrepreneurial Orientation and Business Performance at the Embryonic Stage of Firm Growth. Industrial Marketing Management, 36, 651-661. http://dx.doi.org/10.1016/j.indmarman.2006.04.003

Jolliffe, I. T. (1986). Principal Component Analysis. New York: Springer Science and Business Media.

Kaiser, H. F. (1960). The application of electronic computers to factor analyses. Educ Psychol Meas, 20, $141-151$.

Kaiser, H. F. (1974). An index of Factorial Simplicity. Psychometrika, 39(1), 31-36.

Kraus, S. (2013). The role of entrepreneurial orientation in service firms: empirical evidence from Austria. The Service Industries Journal, 33(5), 427-444. http//dx.doi.org/10.1080/02642069.2011.622373

Kraus, S., Rigtering, J. P. C., Hughes, M., \& Hosman, V. (2012). Entrepreneurial orientation and the business performance of SMEs: a quantitative study from the Netherlands. Rev Manag Sci, 6, 161-182. http://dx.doi.org/10.1007/s11846-011-0062-9

Kreiser, P. M., Marino, L. D., \& Weaver, K. M. (2002). Assessing the Psychometric Properties of the Entrepreneurial Orientation Scale: A Multi-Country Analysis. Entrepreneurship Theory and Practice, 26, 71-94.

Kusumawardhani, A., McCarthy, G., \& Perera, N. (2009). Framework of entrepreneurial orientation and networking: a study of SMEs performance in a developing country. Proceedings of the Australian and New Zealand Academy of Management Conference Adelaide, Australia: Australian and New Zealand Academy of Management.

Lakshman, M., Sinha, L., Biswas, M., \& Charles, M. N. K. (2000). Quantitative Vs qualitative research methods. Indian Journal of Pediatrics, 67(5). http://dx.doi.org/10.1007/BF02820690

Lee, C., Lee, K., \& Pennings, J. M. (2001). Internal Capabilities, External Networks, and Performance: A Study on Technology-Based Ventures. Strategic Management Journal, 22, 615-640. http://dx.doi.org/10.1002/smj.181

Lee, M. S., \& Lim, S. (2009). Entrepreneurial orientation and the performance of service business. Serv Bus, 3, 1-13. http://dx.doi.org/10.1007/s11628-008-0051-5

Lee, S. M., \& Peterson, S. J. (2000). Culture, Entrepreneurial Orientation, and Global Competitiveness. Journal of World Business, 35, 401-416. http://dx.doi.org/10.1016/S1090-9516(00)00045-6

Li, Y. H., Huang, J. W., \& Tsai, M. T. (2009). Entrepreneurial orientation and firm performance: The role of knowledge creation process. Industrial Marketing Management, 38, 440-449. http://dx.doi.org/10.1016/j.indmarman.2008.02.004

Lumpkin, G. T., Cogliser, C. C., \& Schneider, D. R. (2008). Understanding and Measuring Autonomy: An Entrepreneurial Orientation Perspective. Entrepreneurship Theory and Practice, 33(1), 47-69. http://dx.doi.org/10.1111/j.1540-6520.2008.00280.x

Lumpkin, G. T., \& Dess, G. G. (1996). Clarifying the entrepreneurial orientation construct and linking it to performance. Academy of Management Review, 21, 135-172.

Miller, D. (1983). The correlates of entrepreneurship in three types of firms. Management Science, 29(7), 
770-791. http://dx.doi.org/10.1287/mnsc.29.7.770

Moreno, A. M., \& Casillas, J. C. (2008). Entrepreneurial Orientation and Growth of SMEs: A Causal Model. Entrepreneurship Theory and Practice, 32, 507-528. http://10.1111/j.1540-6520.2008.00238.x

Naldi, L., Nordqvist, M., \& Sjoberg, K., \& Wiklund, I. (2007). Entrepreneurial Orientation, Risk Taking, and Performance in Family Firms. Family Business Review, 20, 33-47. http://dx.doi.org/10.1111/j.1741-6248.2007.00082.x

Nunnally, J. C. (1978). Psychometric theory. New York: McGraw-Hill.

Naman, L. J., \& Slevin, P. D. (1993). Entrepreneurship and the Concept of Fit: A Model and Empirical Tests. Strategic Management Journal, 14, 137-153. http://dx.doi.org/10.1002/smj.4250140205

Neumark, D., Wall, B., \& Zhang, J. (2008). Do small businesses create more jobs? New evidence from the Unites States from the National Establishment Time Series. The Review of Economics and Statistics, 93(1), 16-29. http://dx.doi.org/10.3386/w13818

OECD. (1987). The Process of Job Creation and Job Destruction. Employment Outlook, 97-220.

Rauch, A., Wiklund, J., Lumpkin, G., \& Frese, M. (2009). Entrepreneurial orientation and business performance: an assessment of past research and suggestions for the future. Entrepreneurship Theory Pract, 33(3), 761-787. http://dx.doi.org/10.1111/j.1540-6520.2009.00308.x

Runyan, R., \& Swinney, J. (2008). Entrepreneurial Orientation versus Small Business Orientation: What Are Their Relationships to Firm Performance? Journal of Small Business Management, 46(4), 567-588. http://dx.doi.org/10.1111/j.1540-627X.2008.00257.x

Sambharya, R. B. (2011). Security analysts' earnings forecasts as a measure of firm performance: An empirical exploration of its domain. Management Decision, 49(7), 1160-1181. $\mathrm{http}: / / \mathrm{dx}$.doi.org/10.1108/00251741111151190

Schumpeter, J. A. (1942). Capitalism, socialism and democracy. New York: Harper and Brothers.

Slater, S. F., \& Narver, J. C. (2000). The Positive Effect of a Market Orientation on Business Profitability: A Balanced Replication. Journal of Business Research, 48(1), 69-73. http://dx.doi.org/10.1016/s0148-2963(98)00077-0

Su, Z., Xie, E., \& Li, Y. (2011). Entrepreneurial Orientation and Firm Performance in New Ventures and Established Firms. Journal of Small Business Management, 49(4), 558-577. http://dx.doi.org/10.1111/j.1540-627x.2011.00336.x

Tajeddini, K. (2010). Effect of customer orientation and entrepreneurial orientation on innovativeness: Evidence from the hotel industry in Switzerland. Tourism Management, 31, 221-231.

Thomas, A. S., \& Mueller, S. L. (2000). A Case for Comparative Entrepreneurship: Assessing the Relevance of Culture. Journal of International Business Studies, 31(2), 287-301. http://dx.doi.org/10.1057/pelgrave.jibs.8490906

Trompenaars, F. (1994). Riding the waves of culture. London: Nicholas Brealey.

Wiklund, J. (1999). The sustainability of the entrepreneurial orientation-performance relationship. Entrepreneurship Theory and Practice, 24, 37-48.

Wiklund, J., \& Shepherd, D. (2003). Research notes and commentaries Knowledge-based resources, Entrepreneurial orientation and performance of Small and Medium-sized businesses. Strategic Management Journal, 24(13), 1307-1314. http://dx.doi.org/10.1002/smj.360

Wiklund, J., \& Shepherd, D. (2005). Entrepreneurial orientation and small business performance: a configurational approach. Journal of Business Venturing, 20(1), 71-91. http://dx.doi.org/10.1016/j.jbusvent.2004.01.001

Zahra, S., \& Covin, J. (1995). Contextual influence on the corporate entrepreneurship-performance relationship: a longitudinal analysis. Journal of Business Venturing, 10, 43-58. http://dx.doi.org/10.1016/0883-9026(94)00004-E

Zhang, Y., \& Zhang, X. (2012). The effect of entrepreneurial orientation on business performance A role of network capabilities in China. Journal of Chinese Entrepreneurship, 4(2), 132-142. http://dx.doi.org/10.1108/17561391211242744 


\section{Copyrights}

Copyright for this article is retained by the author(s), with first publication rights granted to the journal.

This is an open-access article distributed under the terms and conditions of the Creative Commons Attribution license (http://creativecommons.org/licenses/by/3.0/). 